\title{
SINTESIS DAN KARAKTERISASI AU-SiO MENGGUNAKAN SILICA GEL DENGAN VARIASI pH
}

\author{
Intan Paramudita dan Doty Dewi Risanti \\ ${ }^{1}$ Departemen Teknik Fisika, Fakultas Teknologi Industri - ITS \\ Kampus ITS Keputih, Sukolilo, Surabaya 60111 \\ E-mail: intan.paramudita@gmail.com
}

Diterima: 2 Mei 2018

Diperbaiki: 29 Juni 2018

Disetujui: 23 Juli 2018

\begin{abstract}
ABSTRAK
SINTESIS DAN KARAKTERISASI Au-SiO 2 MENGGUNAKAN SILIKA GEL DENGAN VARIASI pH. Au dan $\mathrm{SiO}_{2}$ banyak digunakan sebagai material tambahan untuk fotoanoda $\mathrm{TiO}_{2}$ karena dapat meningkatkan performansi $D S S C$. Au dapat meningkatkan pemanenan cahaya sedangkan silika bertindak sebagai material penghambur dan penghambat rekombinasi. Penelitian yang dilakukan adalah sintesis dan karakterisasi $\mathrm{Au}-\mathrm{SiO}_{2}$ menggunakan silika gel dengan variasi $\mathrm{pH}$. Silika gel dipilih karena mudah didapat, banyak tersedia dan harga yang murah. Au disintesis berdasarkan metode Turkevich. Larutan silika gel didapatkan dengan cara menggerus silika gel hingga diameter $44 \mu \mathrm{m}$ (325 mesh), kemudia ditambahkan ke dalam campuran etanol, ammonia dan aquadest. Karakterisasi $X R D$ menunjukkan puncak yang mengindikasi adanya $\mathrm{SiO}_{2}$ dan $\mathrm{Au}$ pada semua variasi $\mathrm{pH}$. Ukuran nanopartikel emas yang disintesis pada $\mathrm{pH} 7$ paling kecil dengan jumlah fraksi paling banyak. Sedangkan nanopartikel emas yang disintesis pada $\mathrm{pH} 2$ berukuran paling besar dengan jumlah fraksi paling sedikit. Hal ini menunjukkan bahwa semakin rendah $\mathrm{pH}$, maka semakin cepat proses pengintian dan pertumbuhan nanopartikel, dan sebaliknya. Celah energi $\mathrm{Au}-\mathrm{SiO}_{2}$ menggunakan silika gel dengan variasi $\mathrm{pH}$ sekitar $2,5 \mathrm{eV}$ hingga 3,2 eV. Berdasarkan hasil pengukuran J-V, Au-silika gel yang disintesis pada $\mathrm{pH} 7$ memiliki peningkatan efisiensi tertinggi.
\end{abstract}

Kata kunci: Emas, Silika gel, Nanopartikel, pH

\begin{abstract}
SYNTHESIS AND CHARACTERIZATION AU-SiO, USING SILICA GEL UNDER VARIOUS pH. $\mathrm{Au}$ and $\mathrm{SiO}_{2}$ are widely used as additional material for $\mathrm{TiO}_{2}$ photoanode since it can enhance DSSC performance. Au can increase light harvesting while silica as scatterer and back recombination inhibitor. This work presents synthesis and characterization $\mathrm{Au}-\mathrm{SiO}_{2}$ using silica gel under various $\mathrm{pH}$. Silica gel was chosen since it is easily availableand cheap. Au was synthesized according to the Turkevich method. Silica gel solution were obtained by mechanically grinding the silica gel to diameter $44 \mu \mathrm{m}$ ( $325 \mathrm{mesh})$, subsequently added to mixture of ethanol, ammonia and aquades. XRD characterization showed diffraction peaks indexed to $\mathrm{SiO}_{2}$ and $\mathrm{Au}$. The size of gold nanoparticles at $\mathrm{Au}-\mathrm{SiO}_{2}$ under $\mathrm{pH} 7$ is smallest with largest quantities. While the size of gold nanoparticles at $\mathrm{Au}-\mathrm{SiO}_{2}$ under $\mathrm{pH} 2$ is biggest with least quantities. It was found that the lower the $\mathrm{pH}$, the fastest the nucleation and growth rates of $\mathrm{Au}$ nanoparticles. Hence, it suffers from particles coarsening following Ostwald Ripening mechanism. Energy gap of $\mathrm{Au}-\mathrm{SiO}_{2}$ using silica gel synthesized under various $\mathrm{pH}$ are around $2.5 \mathrm{eV}-3.2 \mathrm{eV}$. According to J-V characterization, Au-silica gel synthesized under $\mathrm{pH} 7$ has the highest photovoltaic parameters.
\end{abstract}

Keywords: Gold, Silica gel, Nanoparticles, pH 


\section{PENDAHULUAN}

$\mathrm{TiO}_{2}$ banyak digunakan sebagai fotoanoda untuk Dye Sensitized Solar Cells (DSSC), tetapi masih memiliki performansi yangterbatas akibat transfer elektron antarmuka yang buruk dan keterbatasan sifat optik [1]. Namun, fotoanoda $\mathrm{TiO}_{2}$ memiliki harga terjangkau, banyak tersedia, ramah lingkungan dan dapat diproses pada suhu ruang.

Berbagai penelitian telah dilakukan sebelumnya sebagai usaha untuk meningkatkan performansi $D S S C$, diantaranya menggunakan emas (Au) dan silika sebagai material tambahan untuk fotoanoda $\mathrm{TiO}_{2}$ [1-5]. Nanopartikel emas memiliki kemampuan penyerapan cahaya tampak yang lebih baik, karena adanya resonansi plasma permukaan [2]. Silika berfungsi sebagai material penghambur yang efisien untuk meningkatkan pemanenan cahaya karena memiliki perbedaan indeks bias yang lebih besar dari media sekitar [3]. Penggunaan silika dapat meningkatkan efisiensi $D S S C$, karena silika berfungsi sebagai material penghamburan dan mencegah rekombinasi [4].

Curved silicate microsheetyang melapisi fotoanoda $\mathrm{TiO}_{2}$ meningkatkan efisiensi DSSC sebagai hasil dari pemanenan cahaya [5]. $\mathrm{pH}$ reaksi pada proses pencampuran berperan penting sebagai pengontrol terhadap ukuran dan bentuk dari nanopartikel emas [6,7].

$D S S C$ dengan perbedaan jumlah $\mathrm{Au} @ \mathrm{SiO}_{2}$ core-shell meningkatkan intensitas penyerapan cahaya pada fotoanoda [8]. Pada penelitian ini menyajikan sintesis dan karaktesisasi $\mathrm{Au}-\mathrm{SiO}_{2}$ menggunakan silica gel dengan variasi $\mathrm{pH}$. Pengaruh dari perbedaan $\mathrm{pH}$ sintesis pada sifat $\mathrm{Au}-\mathrm{SiO}_{2}$ diselidiki.

\section{METODE PERCOBAAN}

\section{Material}

Material yang digunakan pada penelitian ini terdiri dari silica gel, Titanium (III) chloride $\left(\mathrm{TiCl}_{3}, 15 \%\right)$, ammonium $\left(\mathrm{NH}_{3}, 25 \%\right)$, etanol (absolute EtOH, Merck), DI-Water (Sigma-Aldrich), hydrochloric acid ( $\mathrm{HCl}, 37 \%)$, sodium hydroxide (NaOH 28\%, Merck), aquadest, ethanol, (3-Aminoprophyl) trimethoxysilane(APTMS, 97\%, Sigma Aldrich), $\mathrm{HAuCl}_{4 \cdot 3} \mathrm{H}_{2} \mathrm{O}(49 \%$, Sigma Aldrich) dan trisodium citrate (Merck).

\section{Cara Kerja}

Larutan emas disiapkan dengan metode Turkevich. Larutan $\mathrm{HAuCl}_{4} \cdot 3 \mathrm{H}_{2} \mathrm{O}$ didalam air dipanaskan sampai mendidih, kemudian ditambahkan larutan sodiumcitrate dan diaduk. Larutan tetap dipanaskan hingga larutan berubah warna menjadi marah keunguan dan tetap diaduk hingga mencapai suhu ruang [9]. $\mathrm{SiO}_{2}$ disiapkan menggunakan silica gel. Larutan silica gel dihasilkan dengan cara mencampurkan silica gel yang sudah dihaluskan hingga diameter $44 \mu \mathrm{m}$ (325 mesh) sebanyak 0,5 g dengan 39,5 mL etanol, $2 \mathrm{~mL}$ larutan ammonium dan $0,7 \mathrm{~mL}$ aquadest. Nanopartikel emas dengan silica gel disintesis dengan memodifikasi metode yang yang sebelumnya telah dilakukan peneliti sebelumnya [10]. Sebanyak $0,4 \mathrm{~mL}$ larutan (3-Aminoprophyl) trimethoxysilane (1 $\mathrm{mM})$ dicampurkan dengan $30 \mathrm{~mL}$ larutan Au kemudian ditambahkan dengan larutan silica gel, $\mathrm{pH}$ akhir pencampuran ini adalah 10. Larutan tersebut kemudian dititrasi menggunakan $\mathrm{HCl}[2 \mathrm{M}]$ hingga $\mathrm{pH} 2, \mathrm{pH} 4$, $\mathrm{pH} 6$, dan $\mathrm{pH} 7$ dan dihasilkan endapan putih. Kemudian larutan didiamkan selama 24 jam dan disaring, serta dicuci beberapa kali dengan aquadest untuk menghilangkan kandungan asam, alkali dan garam. Selanjutnya didkeringkan selama 24 jam pada suhu $80^{\circ} \mathrm{C}$.

Struktur kristal serbuk ditentukan oleh X-Ray Diffraction (XRD) menggunakan Phillips X'pert MPD $(40 \mathrm{kV}, 30 \mathrm{~mA})$ dengan radiasi $\mathrm{Cu} \mathrm{K} \alpha(\lambda=0,154 \mathrm{~nm})$. Pola difraksi diperoleh untuk sudut $15^{\circ}$ hingga $100^{\circ}(2 \theta)$. Morfologi diobservasi dengan Scanning Electron Microscope (SEM) Hitachi SU 3500. Spektrum FT-IR menggunakan Thermo Scientific Nicolet iS10. Sifat optic diukur menggunakan $U V$-Vis Absorption Spectroscopy, UV-Vis Lambda 750.

\section{HASIL DAN PEMBAHASAN}

Terdapat 4 variasi yang $\mathrm{pH}$ diinvestigasi dalam penelitian ini, diantaranya $\mathrm{pH} 7, \mathrm{pH} 6, \mathrm{pH} 4$ dan $\mathrm{pH} 2$. Karakterisasi $X R D$ dari Gambar 1. menunjukkan puncak difraksi untuk Au-silica gel yang disintesis dengan variasi $\mathrm{pH}$, mengindikasi $\mathrm{SiO}_{2}$ dan $\mathrm{Au}$. Au memiliki puncak difraksi yang berbeda untuk setiap sampel. Secara umum puncak yang didapatkan untuk nanopartikel Au sekitar $38,1^{\circ}$ dengan sedikit pergeseran dikarenakan zero drift dari peralatan $X R D$.

Dari Gambar 1 puncak difraksi utama nanopartikel Au disekitar $2 \theta=\sim 38,14^{\circ}$, sesuai dengan bidang (111) di nanopartikel Au [8]. Terdapat puncak lain untuk pH 7 , diantaranya di $44,39^{\circ}, 64,6^{\circ}$, dan $77,1^{\circ}$ sesuai dengan

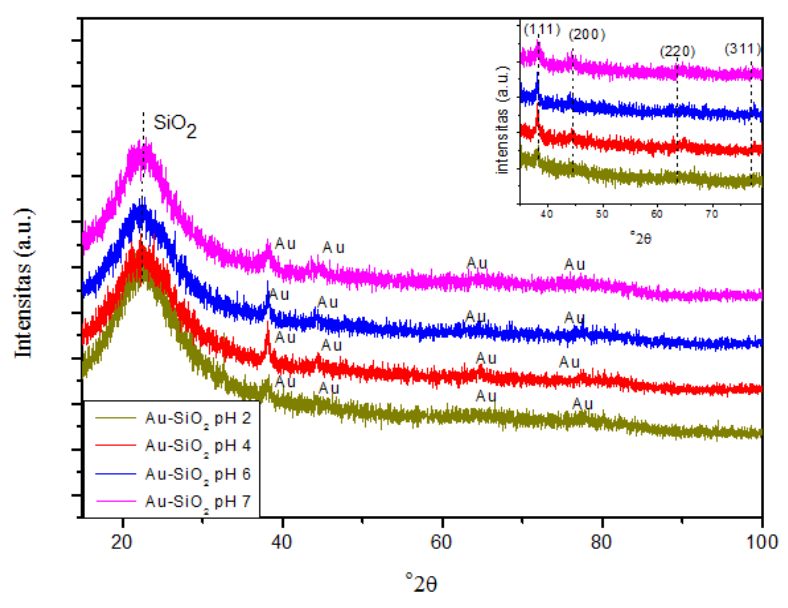

Gambar 1. XRD dari Au-silica gel yang disintesis dengan variasi $\mathrm{pH}$ (intensitas digeser secara vertical untuk kejelasan). 
bidang (200), bidang (220), dan bidang (311) pada nanopartikel $\mathrm{Au}$ [6]. Untuk pH 6, pH 4, and $\mathrm{pH} 2$, terdapat bidang (200) pada nanopartikel emas di $44,04^{\circ}, 43,67^{\circ}$, dan $44,1^{\circ}$. Selain itu, puncak di $77,2^{\circ}$ untuk pH $6,77,4^{\circ}$ untuk $\mathrm{pH} 4$, dan $77,7^{\circ} \mathrm{pH} 2$, sesuai dengan puncak difraksi nanopartikel Au bidang (311). Karakterisasi XRD dari Gambar 1. juga menunjukkan bahwa $\mathrm{SiO}_{2}$ dalam fasa amorf. Untuk fasa amorf, X-Ray akan dihamburkan ke berbagai arah dan didistribusikan ke sepanjang $2 \theta$. Puncak difraksi $\mathrm{SiO}_{2}$ sekitar $2 \theta=22^{\circ}$ untuk semua sampel.

Gambar SEM ditunjukkan pada Gambar 2. Hasil tersebut menunjukkan bahwa silica gel memiliki bentuk yang tidak beraturan.

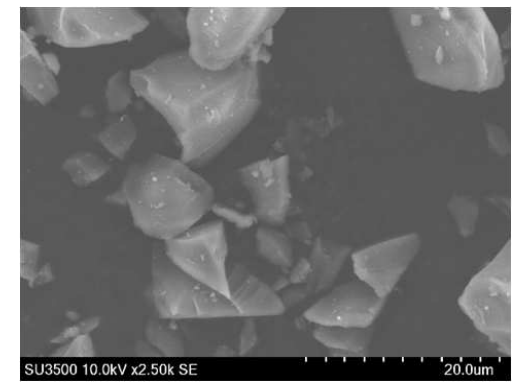

Gambar 2. SEM Au-silika gel yang disintesis dengan variasi $\mathrm{pH}$.

Ukuran kristal Au yang dihitung berdasarkan persamaan Scherrer dan fraksi disajikan pada Tabel 1.

Tabel 1. Ukuran kristal dan fraksi Au Au-silica gel yang disintesis dengan variasi $\mathrm{pH}$.

\begin{tabular}{ccc}
\hline $\begin{array}{c}\text { Variasi pH } \\
\text { Au-silica gel }\end{array}$ & $\begin{array}{c}\text { Ukuran kristal } \\
(\mathrm{nm})\end{array}$ & $\begin{array}{c}\text { Fraksi Au } \\
(\%)\end{array}$ \\
\hline pH 7 & 8,49 & 45,93 \\
pH 6 & 20,70 & 41,73 \\
pH 4 & 24,83 & 39,57 \\
pH 2 & 26,97 & 18,9 \\
\hline
\end{tabular}

Ukuran nanopartikel Au pada Au-silica gel yang disintesis pada pH 7 memiliki ukuran paling kecil sedangkan yang disintesis pada $\mathrm{pH} 2$ memiliki ukuran paling besar. Prosentase nanopartikel Au pada Au-silica gel yang disintesis pada $\mathrm{pH} 2$ paling sedikit, sedangkan yang disintesis pada $\mathrm{pH} 7$ memiliki prosentase paling banyak. Hal ini menunjukkan bahwa semakin rendah $\mathrm{pH}$ sintesis, semakin cepat proses pengintian dan tingkat pertumbuhan partikel.

Berdasarkan Ostwald ripening atau particle coarsening, terdapat 3 fasa pembentukan nanopartikel $\mathrm{Au}$, yaitu pengintian, pertumbuhan lambat dan pertumbuhan cepat [12]. Fasa pertama adalah pembentukan inti secara cepat, diikuti oleh pertumbuhan inti menjadi patikel yang lebih besar, kemudian partikel tumbuh secara cepat hingga ukuran akhir. Nanopartikel $\mathrm{Au}$ yang disintesis bervariasi bergantung pada $\mathrm{pH}$ sintesis. Untuk pH rendah, pH 3,7 hingga 6,5, pembentukan partikel melalui nukleasi selama 10 detik, diikuti oleh pertumbuhan acak secara cepat dan diakhiri dengan intraparticle ripening. Untuk $\mathrm{pH}$ yang lebih tinggi, pH 6,6 hingga 7,7, pembentukan partikel membutuhkan waktu yang pengintian yang lebih lama yaitu 60 detik diikuti pertumbuhan lambat[13]. Ukuran kristal emas pada Tabel 1, memiliki kesesuaian dengan particle coarsening mechanism, ukuran rata-rata kristal meningkat seiring penurunan $\mathrm{pH}$ sintesis.

Gambar 3. menggambarkan spektrum FT-IR pada rentang $500 \mathrm{~cm}^{-1}$ hingga $4000 \mathrm{~cm}^{-1}$ untuk Au-silica gel yang disintesis dengan variasi $\mathrm{pH}$. Pengaruh $\mathrm{pH}$ selama sintesis tidak dapat terlihat secara jelas. Puncak luas pada $3370 \mathrm{~cm}^{-1}$ sesuai dengan $\mathrm{H}-\mathrm{O}-\mathrm{H}$ stretching karena penyerapan air. Puncak disekitar $1600 \mathrm{~cm}^{-1}$ dan $1060 \mathrm{~cm}^{-1}$ merupakan puncak H-O-H bending of water, dan Si-O stretching. Puncak disekitar $750 \mathrm{~cm}^{-1}$ adalah $\mathrm{Si}-\mathrm{O}-\mathrm{Si}$ bending $[14,15]$. Ikatan M-O dapat terdeteksi dengan IR Spectroscopy di daerah $1060 \mathrm{~cm}^{-1}$ [16].

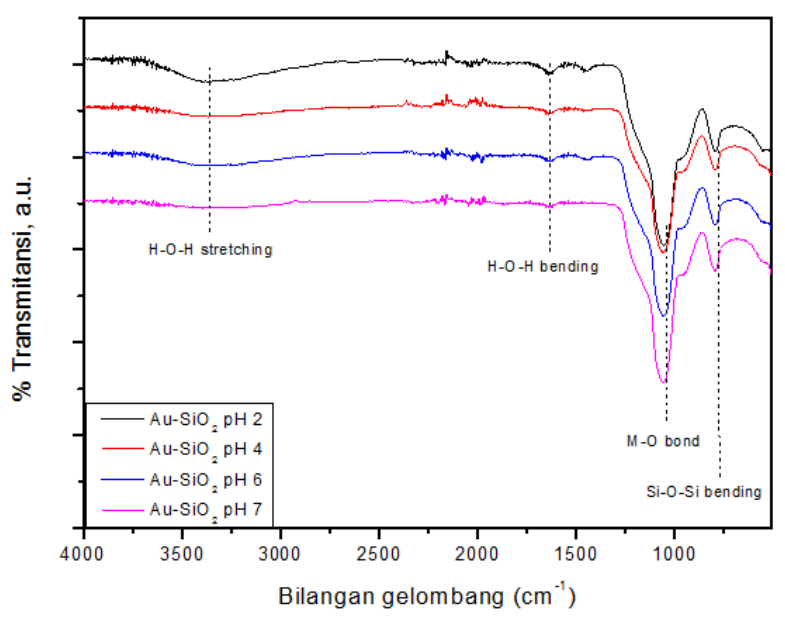

Gambar 3. Spektrum FT-IR Au-silica gel yang disintesis dengan variasi $\mathrm{pH}$ (transmitansi digeser secara vertical untuk kejelasan).

Gambar 4. menampilkan celah energi pada Au-silica gel yang disintesis dengan variasi $\mathrm{pH}$. Celah energi didefinisikan sebagai perbedaan antara pita konduksi dan pita valensi. Celah energi ditentukan dengan Persamaan (1) hingga Persamaan (3).

$$
\begin{aligned}
& (\alpha h v)^{2}=\left(\frac{\alpha h c}{\lambda}\right)^{2} \\
& \alpha=\frac{\ln (100 / T)}{d} \\
& E(e V)=h v=\frac{h c}{\lambda}
\end{aligned}
$$

Transmitansi $(\mathrm{T})$ dan panjang gelombang $(\lambda)$ merupakan hasil dariUV-Vis Spectroscopy. Au-silica gel yang disintesis dengan variasi $\mathrm{pH}$ memiliki celah energi

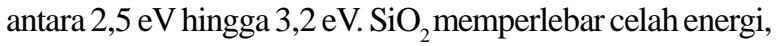
sedangkan nanopartikel Au mempersempit celah energi [17]. 


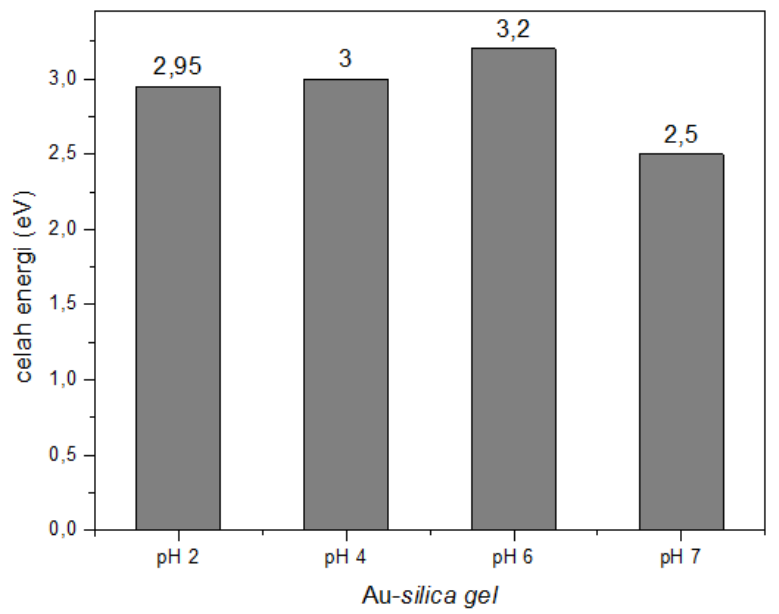

Gambar 4. Celah energi Au-silika gel yang disintesis dengan variasi $\mathrm{pH}$.

Untuk mengetahui pengaruh Au-silica gel yang disintesis dengan variasi $\mathrm{pH}$ pada besarnya foto voltaik pada $D S S C$, $\mathrm{TiO}_{2}$ yang disintesis dengan $\mathrm{TiCl}_{3}$ digabungkan dengan Au-silica gel sebagai foto anoda. Besarnya fotovoltaik bergantung pada beberapa faktor. Kenaikan celah energi berpengaruh terhadap penurunan arus short-circuit. Arusshort-circuit (Gambar 5) memiliki kesesuaian dengan celah energi (Gambar 4). seperti yang telah diketahui, kontak langsung antara Au dan elektrolit menghasilkan proses rekombinasi dan menurunkan performansi DSSC [1].

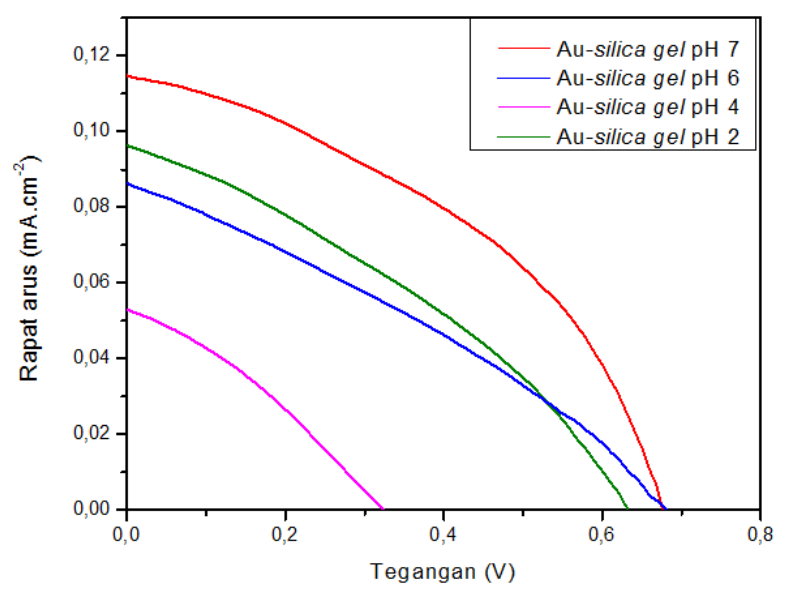

Gambar 5. (a). Kurva rapat arus - tegangan (J-V) $\mathrm{Au}$-silica gel yang disintesis dengan variasi $\mathrm{pH}$.

Shunt resistance $\left(\mathrm{R}_{\mathrm{sh}}\right)$ menghasilkan kurva $J-V$ yang tidak ideal untuk solar cell. Adanya $\mathrm{R}_{\mathrm{sh}}$ menyebabkan rugi daya, yang dihasilkan karena cacat fabrikasi. $\mathrm{R}_{\mathrm{sh}}$ yang rendah menyebabkan rugi daya pada solar cells dengan menyediakan aliran arus alternatif untuk cahaya yang menghasilkan arus seperti pada Persamaan (4).

$$
I=I_{L}-I_{0} \exp \left[\frac{q V}{n k T}\right]-\frac{V}{R_{s h}}
$$

Dimana:

$$
\begin{aligned}
I & =\text { Arus keluaran sel } \\
I_{L} & =\text { Cahaya yang menghasilkan arus } \\
V & =\text { Tegangan } \\
T & =\text { Suhu } \\
q & =\text { Konstan } \\
k & =\text { Konstan } \\
n & =\text { Faktor ideal } \\
R_{s h} & =\text { Shunt resistance }
\end{aligned}
$$

Aliran ini menurunkan jumlah arus yang mengalir melalui sambungan solar cell dan menurunkan tegangan solar cell [18]. Cacat berasal dari proses fabrikasi yang tidak sempurna. Pasta foto anoda menempel dengan lemah ke kaca FTO. Sabagian pasta terlepas selama proses perendaman pewarna.

Parameter fotovoltaik tertinggi diperoleh dari DSSC yang menggunakan $\mathrm{TiO}_{2} / \mathrm{Au}$-silica gel disintesis pada $\mathrm{pH} 7: V_{o c}=0,775 \mathrm{~V}, J_{s c}=0,116 \mathrm{~mA} / \mathrm{cm}^{2} \mathrm{dan}$ $\eta=0,031 \%$. Au-silica gel yang disintesis pada $\mathrm{pH} 7$ memiliki parameter fotovoltaik tertinggi karena memiliki proses fabrikasi terbaik, sedangkan Au-silica gel yang disintesis pada pH 6 memiliki parameter fotovoltaik terendah karena memiliki proses fabrikasi yang kurang baik yang menyebabkan cacat.

\section{KESIMPULAN}

$\mathrm{Au}-\mathrm{SiO}_{2}$ menggunakan silika gel yang disintesis dengan variasi $\mathrm{pH}$ telah berhasil disintesis. Hasil XRD menunjukkan bahwa semakin rendah $\mathrm{pH}$ titrasi maka semakin cepat proses pengintian dan kecepatan pertumbuhan nanopartikel Au. Sampel terbaik adalah $\mathrm{Au}-\mathrm{SiO}_{2}$ menggunakan silika gel dengan $\mathrm{pH}$ titrasi 7, karena memiliki parameter fotovoltaik tertinggi. Celah energi $\mathrm{Au}-\mathrm{SiO}_{2}$ menggunakan silika gel dengan variasi pH sekitar 2,5 eV hingga 3,2 eV.

\section{UCAPAN TERIMAKASIH}

Penulis berterimakasih kepada Direktorat Jenderal Riset, Teknologi, dan Pendidikan Tinggi, Kementrian Riset, Teknologi, dan Pendidikan Tinggi no. kontrak 669/ PKS/ITS/2017 skema Penelitian Unggulan PT. Penulis, Intan Paramudita juga berterimakasih kepada LPDP yang telah memberikan beasiswa pendidikan kepada penulis.

\section{DAFTAR ACUAN}

[1]. A. Pandikumar, S. Lim, S. Jayabal, N. M. Huang, H. N. Lim, R. Ramaraj. “Titania@gold Plasmonic Nanoarchitectures: An Ideal Photoanode for DyeSensitized Solar Cells.” Renewable and Sustainable Energy Reviews, vol. 60, pp. 408-420, Feb. 2016.

[2]. M. Ye, H. Zhou, T. Zhang, Y. Zhang, and Y. Shao. "Preparation of $\mathrm{SiO}_{2} @ \mathrm{Au} @ \mathrm{Tio}_{2}$ Core-Shell Nanostructures and Their Phoyocatalyst Activities 
Under Visible Light Irradiation.” Chem. Eng. J., vol. 226, pp. 209-216, April 2013.

[3]. Y. Wang, E. Chen, H. Lai, B. Lu, Z. Hu, X. Qin, G. Du. "Enhanced Light Scattering and Photovoltaic Performance for Dye-Sensitized Solar Cells by Embedding Submicron $\mathrm{SiO}_{2}-\mathrm{TiO}_{2}$ Coreshell Particles in Photoanode." Ceramics International, vol. 39, pp. 5407-5413, Dec. 2012.

[4]. Tanvi, A. Mahajan, R. K. Bedi, S. Kumar, V. Saxena, and D. K. Aswal. "Efficiency Enhancement in Dye Sensitized Solar Cells Using Dual Function Mesoporous Silica as Scatterer and Back Recombination Inhibitor." Chem. Phys. Lett., vol. 658, pp. 276-281, June 2016.

[5]. Z. Wang, Q. Tang, B. He, H. Chen, L.Yu. "Efficient Dye-Sensitized Solar Cells from Curved Silicate Microsheet Caged $\mathrm{TiO}_{2}$ Photoanodes. An avenue of enhancing light harvesting." Electrochimica Acta, vol. 178, pp. 18-24, July 2015.

[6]. C. Li, D. Li, G. Wan, J. Xu and W. Hou, "Facile Synthesis of Concentrated Gold Nanoparticles with Low Size-Distribution in Water: Temperature and pH controls". Nanoscale Research Letters, vol. 6, pp. 1-10, 2011.

[7]. X. Ji, X. Song, J. Li, Y. Bai, W. Yang and X. Peng. "Size Control of Gold Nanocrystals in Citrate Reduction The Third Role of Citrate.” J. Am. Chem. Soc, vol. 129, pp. 13939-13948, Sep. 2007.

[8]. L. Bai, M. Li, K.Guo, M. Luoshan, H. F. Mehnane, L. pei, M. Pan, L. Pao, X. Zhao. "Plasmonic Enhancement of The Performance of DyeSensitized Solar Cell by Core-Shell AuNRs@ $\mathrm{SiO}_{2}$ in Composite Photoanode." Journal of Power Sources, vol. 272, pp. 1100-1105, Sept 2014.

[9]. J. Kimling, M. Maier, B. Okenve, V. Kotaidis, H. Ballot, and A. Plech. "Turkevich Method for Gold Nanoparticle Synthesis Revisited.” J. Phys. Chem., vol. 110, pp. 15700-15707, May 2006.

[10]. H. Li, W. Hong, F. Cai, Q. Tang, Y. Yan, X. Hu, B. Zhao and Z. Xu. "Au@ $\mathrm{SiO}_{2}$ Nanoparticles Coupling Co-Sensitizers for Synergic Efficiency
Enhancement of Dye Sensitized Solar Cells." Journal of Material Chemistry, vol 22, pp. 24734-24743, Sept 2012.

[11]. H. Tyagi, A. Kushwaha, A. Kumar, and M. Aslam, “ A Facile pH Controlled Citrate-Based Reduction Method for Gold Nanoparticle Synthesis at Room Temperature." Nanoscale Research Letters, vol. 11, pp. 362-373, 2016.

[12]. J. Polte, T. T. Ahner, F. Delissen, S. Sokolov, F. Emmerling, A. F. Thunemann, and R. Kraehnert. "Mechanism of Gold Nanoparticle Formation in the Classical Citrate Synthesis Method Derived from Coupled In Situ XANES and SAXS Evaluation." J. Am. Chem. Soc., vol. 132, pp. 1296-1301, July 2010.

[13]. N. T. K. Thanh, N. Maclean, and S. Mahiddine. "Mechanism of Nucleation and Growth of Nanoparticles in Solution." Chemical Reviews, vol. 114,pp. 7610-7630, 2014.

[14]. B. J. Saikia and G. Parthasarathy. "Fourier Transform Infrared Spectroscopic Characterization of Kaolinite from Assam and Meghalaya, Northeastern India.” J. Mod. Phys., vol. 1, pp. 206-210, Oct. 2010.

[15]. A. A. Kamnev. "Infrared Spectroscopy in Studying Biofunctionalised Gold Nanoparticles." Nanomater Imaging Techniques, Surface Studies, and Applications, Springer Proceedings in Physics, vol. 146, pp. 35-50, Sep. 2013.

[16]. I. E. Wachs. "Infrared spectroscopy of supported metal oxide catalysts." Colloids Surfaces A: Physicochem. Eng. Aspecs, vol. 105, pp. 143-149, 1995

[17]. Q. Sun, Q. Wang, B. K. Rao, and P. Jena. "Electronic Structure and Bonding of $\mathrm{Au}$ on $\mathrm{a} \mathrm{SiO}_{2}$ Cluster A Nanobullet for Tumors." Physical Review Letters, vol. 93, pp. 1-4, Oct. 2004.

[18]. C. Honsberg, S. Bowden, "Welcome to the Photovoltaic Education Network.” Internet: https:/ /pveducation.org, 2018 [August 13, 2018]. 